\title{
The Effect of Board Composition on the Financial Performance of Commercial Banks in Cameroon
}

\author{
Prof Emmanuel Kamdem, Dr Gladys Njoukiang Asaah \\ Certified Accountant, Pan African Institute for Development, Yaoundé, Cameroon \\ Investment Management, Pan African Institute for Development, Yaoundé, Cameroon
}

\author{
*Corresponding Authors: Prof Emmanuel Kamdem, Certified Accountant, Pan African Institute for \\ Development, Yaoundé, Cameroon
}

\begin{abstract}
Measurement of financial performance of enterprises is an important Component required for investment decision making. Previous research has indicated a relationship between leadership and financial performance of enterprises. This study investigated the effect of board composition on the financial performance of commercial banks in Cameroon. Ex-post facto research design was adopted for the study. The data used for this study was secondary data derived from the audited financial statements of the selected registered commercial banks in Cameroon. A five years period from 2015-2019 was the period of concentration. Data collected was analysed using panel data regression analysis. Findings revealed that the board composition which is the proportion of non-executive directors to the executive directors on the board recorded a mean of $75 \%$. This means that on average of $75 \%$ of the board members are outside directors (non-executive directors) in Cameroon based banks. Also, the regression analysis indicated that there exist a negative (-.463) correlation between board composition (proposition of non-executive directors) and the financial performance of commercial banks in Cameroon as measured by ROA. This result was equally significant at $t=-6.052$ and $p=.000$. The negative sign observed here means that an increase in the nonexecutive directors on the board of directors will lead to a corresponding decrease in the financial performance of commercial banks in Cameroon. The study therefore recommended that commercial banks in Cameroon should strike a fair balance between the proportion of non-executive and executive directors on their board for improve performance.
\end{abstract}

Keywords: Board composition, Executive Directors, Financial Performance, Commercial Banks

\section{INTRODUCTION}

The main driver of business engagement is to maximise shareholders net value.Investment is the postponement of present consumption for future gratifications. Therefore, investors will be interested in the value of the expected return on their investment ascompares to their opportunity cost. Successful leadership represents one of the most important factors that contribute to the enterprise success. Koontz et al. (1990) define leadership as a process of influencing employees in order to motivate and encourage them to achieve the enterprise's goals. Griffin(2002) believes that leadership is both a process and a trait. As a process, leadership represents the focus on activities that a leader takes, and as a trait, leadership represents leader's traits. Leadership can also be defined as the skill of encouraging employees to participate voluntarily in the realization of enterprise's goals (Rožman et al., 2017).It is important to point effective leadership leads to increase in the shareholder value. The responsibilities to lead organisations lies with the board of directors. These responsibilities of the directors include setting the company's strategic aims, providing the leadership to put them into effect, supervising the management of the business and reporting to shareholders on their stewardship which constitute the core of corporate governance. The Board's actions are subjected to laws, regulations and the shareholders in general meeting (Olayiwola, 2010).

Boards of directors are responsible for the governance of their companies. The shareholders' role in governance is to appoint the directors and the auditors and to satisfy themselves that an appropriate governance structure is in place. Corporate governance is a set of procedures, policies and laws that influences the administration processes of a company. This is the relationships among the many 
stakeholders involved and the goals for which the corporation is governed. In modern business corporations, the main external stakeholder groups are shareholders, debt holders, trade creditors, suppliers, customers and communities affected by the corporations' activities. Internal stakeholders are the board of directors, executives, and other employees (Akpan\&Riman, 2012).

The term corporate governance came into popular use in the 1980s to broadly describe the general principles by which the business and management of companies were directed and controlled. Although its usage is now common, and the objectives to be achieved thereby generally understood, there is no universally accepted definition of corporate governance. Although the utility of definitions is invariably exaggerated, definitions do have the advantage of providing a general framework for discussion and debate. For this purpose, and in view of the comparative infancy of the subject in Cameroon, a limited discussion of the definition of corporate governance is provided below (Anderson et al. 2004). Given the fury of activities that have affected the efforts of banks to comply with the various consolidation policies and the antecedents of some operators in the system, there are concerns on the need to strengthen corporate governance in banks. This will boost public confidence and ensure efficient and effective functioning of the banking system (Soludo, 2004a). According to Heidi and Marleen (2003:4), banking supervision cannot function well if sound corporate governance is not in place. Consequently, banking supervisors have strong interest in ensuring that there is effective corporate governance at every banking organization. Changes in bank ownership and subsequently board composition during the 1990s and early 2000s substantially altered governance of the world's banking organization (Mayes et al., 2001). These changes in the board composition of banks raised very important policy research questions. The fundamental question is how do these changes affect bank performance?

Corporate governance in Cameroon came into existence since 1968 the establishment of the Companies Act of 1968 which regulates the running of companies in relation to the roles of the board of directors and the members in general meeting. Corporate governance in Cameroon especially in the banking industry was re-strengthening in 1992 by the creation of the Banking Commission for Central Africa with its acronym COBAC. The creation of COBAC was necessitated by the collapsed of high-profile banks in Cameroon like Bank of Cameroon Le Meridiane B.I.A.O. Bank and B.I.C.I.C. all of which were mostly blamed on poor corporate governance.

It is therefore necessary to point out that the concept of board composition of banks and very large firms have been a priority on the policy agenda in developed market economies for over a decade. Further to that, the concept is gradually warming itself as a priority in the African continent. Indeed, it is believed that the Asian crisis and the relatively poor performance of the corporate sector in Africa have made the issue of corporate governance a catchphrase in the development debate (Berglof and Von -Thadden, 1999). The banking sector of the developing nations among other sectors has also witnessed several cases of collapses, some of which include; in Nigeria Alpha Merchant Bank, Savannah Bank and SocieteGenerale Bank, and in Kenya, Continental Bank of Kenya, Capital Finance Ltd, Consolidated Bank of Kenya and Trust Bank of Kenya (Akpan, 2007).

Board composition is a subset of corporate governance in firms, banks included; wherecorporate governance in a particular firm improves then firm's performance will also increase (Khan \&Awan, 2012). One characteristic of board composition is the board size; theoretically, large boards are expected to depict an inverse relationship with financial performance. Problems of poor communication and hampered decision-making weakenthe effectiveness and efficiency of larger boards relative to smaller ones (Guest, 2009). According to agency theory (Jensen \&Meckling, 1976), boards of directors should be structured to safeguard the principals (owners') best interests by limiting agency problems (where firm managers might pursue self-advancing goals through board resolutions). Thus, board composition influences financial performance positively; only positive net present value projects are vouched for in board decisions. However, the stakeholder theory (Freeman, 1984) posits that boards are often composed of stakeholders; each stakeholder has some interest to safeguard through the board of directors, where these interests are not aligned the effect on financial performance could be negative.

Since in the late 1980s with the introduction of Structural Adjustment Programme (SAP) till now the Cameroonian banking industry has witnessed a lot of corporate restructuring with the ownership of several banks transformed from one form to the other. For example, the in 1989 Cameroon Bank 
Corporation $(\mathrm{CBC})$ had a split-winding transfer, with the transfer of compromised debt and a merger of good assets with the Commercial bank of Credit Lyonnais (SCB-CL). The same 1989 witnessed the liquidation and closure of the Rural Development Fund (Fonadis), The Development Bank (BCD) of Cameroon, Banque Paribas (Paribas), Bank of Cameroon (Cambank) and the split-winding of the Bank of Credit and Commerce Cameroon (BCCC), with the transfer of good assets at Standard Chartered Bank Cameroon (SCBC). In 1990, International Bank for Trade and Industry of Cameroon (BICICI) was liquidated and replaced by International Bank of Cameroon for savings and credit (BICEC). In the 2000s, Bank Atlantigue acquired Amity, Ecobank acquired Oceanic Bank and host foreign nationals like the Moroccan, the Nigerian, the French interested in investing in banking sector of Cameroon. Therefore, there is the need for a good corporate governance structure in Cameroon so that depositors' funds could be well secured.

In Cameroon, little empirically studies have been carried out on board composition and firms' performance.In order to address these deficiencies, this study examined the role of Boardcomposition in the financial performance of Cameroonian commercial banks. Unlike other prior studies, this study is not restricted to the framework of the OECD principles, which is based primarily on shareholder sovereignty.While it is logical (but not undisputed) to suppose that the managerial abilities of the board of directors would have a significant impact on the entity's financial performance, it is however not clear-cut whether the board's composition would significantly influence the entity's performance.

\section{HYPOTHESIS}

There is no significant relationship between the board composition and financial performance of commercial banks in Cameroon.

\section{LITERATURE REVIEW}

\subsection{Board Composition and Financial Performance}

The board of directors can play an important role in improving corporate governance and the value of a firm (Hanrahan et al. 2001). The value of a firm is also improved when the board performs its fiduciary duties such as monitoring the activities of management and selecting the staff for a firm. The board can also appoint and monitor the performance of an independent auditor to improve the value of a firm. The board of directors can resolve internal conflicts and decrease the agency cost in a firm. The members of a board should also be accountable to the shareholders for their decisions as argued by Vance (1983), Anderson and Anthony (1986), Nikomborirak (2001) and Tomasic et al. (2003).

The board consists of two types of directors; outsider (independent) and insider directors. The majority of directors in a board should be independent to make rational decisions and create value for the shareholders. The role of independent directors is important to improve the value of a firm as they can monitor the firm and can force the managers to take unbiased decisions. The independent directors can also play a role of a referee and implement the principles of corporate governance that protect the rights of shareholders (Bhagat and Jefferis, 2002; Tomasic et al. 2003).

Similarly, internal directors are also important in safeguarding the interests of shareholders. They provide the shareholders with important financial information, which will decrease the information asymmetry between managers and shareholders as argued by Bhagat and Black (1999) and Bhagat and Jefferis (2002). The board size should be chosen with the optimal combination of inside and outside directors for the value creation of the investors. The boards of directors in the developing market are unlikely to improve the value of a firm, as the weak judiciary and regulatory authority in this market enables the directors to be involved in biased decision-making that serves the interests of the majority shareholders and the politicians providing a disadvantage to the firm (Asian Development Bank, 1997).

The composition of board members has been proposed to help reduce the agency problem (Weisbach, 1988). Empirical studies on the effect of board membership and structure on performance generally show results either mixed or opposite to what would be expected from the agency cost argument. While some studies find better performance for firms with boards of directors dominated by outsiders (Pfeffer and Salancik 1978; Ogus, 1994;1998; Pearce and Zahra 1992; Vafeas, 1999), others find no such relationship in terms of accounting profits or firm's value (Weisbach, 1988; Daily and Dalton, 1992; Mehran 1995; Daily and Ellstrand, 1996; Rosenstein and Wyatt 1997; Klein 1998; Weir and 
Laing 2001 and Bhagat and Bolton 2005). Daily and Dalton (1992) provided analyses of 54 empirical studies of board composition and 31 empirical studies of board leadership structure and their relationships to firm financial performance. They find little evidence of a relationship between board composition or leadership and firm financial performance. This is also evident in the study by Hermalin and Weisbach (1999) and Bhagat and Black (2002).

As it is the case in many family-based Asian banks (Malaysian banks), boards dominated by insiders are not expected to play their role as effective monitors and supervisors of management. This is particularly when the board chairperson is also the firm's CEO. In addition, outside directors provide firms with windows or links to the outside world, thereby helping to secure critical resources and expand networking (Daily and Ellstrand, 1996).

In the case of a sample of 228 small, private firms in Shanghai in the People's Republic of China, Liang and Li (1999) cited in Sang-Woo and Lum (2004), reported that the presence of outside directors is positively associated with higher returns on investment, though they do not find such a relationship for board size or the separation of the positions of CEO and board chairperson. Furthermore, Bohren and Bernt (2003) showed that the amount of stock owned by individual outside directors is significantly correlated with various measures of firm performance as well as CEO turnovers in poorly performing companies.

Baysinger and Butler (1990) and Rosenstein and Wyatt (1997) showed that the market rewards firms for appointing outside directors. Brickley, Coles and Terry (1994)find a positive relationship between the proportion of outside directors and the stock market reaction to poison pill adoptions; and Anderson, Mansi and Reeb (2004) in their study showed that the cost of debt, as proxied by bond yield spreads, is inversely related to board independence. However, Fosberg (1989) investigated the relationship between the proportion of outside directors and various performance measures and finds no relationship between the two variables. Hermalin and Weisbach (1999) also observed no association between the proportion of outside directors and Tobin's Q; and Bhagat and Black (2002) find no linkage between the proportion of outside directors and Tobin's Q, return on assets, asset turnover and stock returns.

Sanda et al. (2005), used a pooled OLS regression analysis of quoted companies in Nigerian stock exchange firm to find no evidence to support the idea that boards with higher proportion of outside directors perform better than other firms. Attiya and Robina (2007) in Pakistan analysed the relationship between firm value (Tobin's Q) and governance sub-indices (board ownership and shareholdings). The result indicates that corporate governance does matter in Pakistan and that board composition has significant effects on firm performance.

Thus, the relationship between the proportions of outside directors, a proxy for board independence, and firm performance is mixed. Studies using financial statement data and Tobin's Q find no link between board independence and firm performance, while those using stock returns data or bond yield data find a positive link.

\section{Methodology}

The research design that was adopted for the study was ex-post facto research design. This design was considered appropriate because the researcher had no control over the dependent and the independent variables being studied. At the time of the study, the manifestation in the dependent and independent variables had already occurred. Thus, the researcher only studied the variables the way they were and, in the process, to describe the relationship existing between the variables. The population for this study consists of all the 15 registered commercial banks in Cameroon as at 2020 . The judgmental sampling technique was used in selecting the 10 listed banks out of the 15 registered commercial banks.

The data used for this study was secondary data derived from the audited financial statements of the selected registered commercial banks in Cameroon. A five years period from 2015-2019 will be the period of concentration. This study also made use of books and other related materials especially the BEAC and Douala Stock exchange. 


\section{MOdel SPECIFICATION}

This study employed a modified version of the econometric model of Miyajima et al (2003) as adopted by Coleman and Nicholas- Biekpe (2006). The Econometric model of Miyajima et al (2003) is therefore seen below as;

$\mathrm{Y}_{\mathrm{it}}=\beta_{\mathrm{o}}+\beta_{2} \mathrm{BCOMP}_{\mathrm{t}}++e_{t}$

Where:

$Y_{i t}$ represents firm performance variables which are: return on capital employed, earnings per share, return on assets and return on equity for banking firms at time $t$.

$G_{i t}$ is a vector of corporate governance variable of Board Composition (BCOMP).

Based on the fact that we employed different governance and performance proxies, the above model is therefore modified to determine the relationship between bank performance and corporate governance of banks in Cameroon. In doing this we therefore developed two simple definitional models to guide our analyses. The model is as follows;

$\mathrm{ROA}_{\mathrm{it}}=\beta_{\mathrm{o}}+\beta_{1} \mathrm{BCOMP}_{\mathrm{t}} e_{t}$

Where:

ROA $=$ Returnon Asset

BOS= Board Composition

\section{RESUlT AND DISCUSSION}

Table1. Regression Result of the relationship between board and financial performance of commercial banks in Cameroon

\begin{tabular}{|c|c|c|c|c|c|c|}
\hline \multicolumn{7}{|c|}{ Coefficients $^{\mathrm{a}}$} \\
\hline \multirow{2}{*}{\multicolumn{2}{|c|}{ Model }} & \multicolumn{2}{|c|}{ Unstandardized Coefficients } & \multirow{2}{*}{$\begin{array}{c}\begin{array}{c}\text { Standardized } \\
\text { Coefficients }\end{array} \\
\text { Beta } \\
\end{array}$} & \multirow[t]{2}{*}{$\mathrm{T}$} & \multirow[t]{2}{*}{ Sig. } \\
\hline & & B & Std. Error & & & \\
\hline 1 & (Constant) & 10.444 & 1.537 & & 6.797 & .000 \\
\hline & BCOM & -.463 & .076 & -.359 & -6.052 & .000 \\
\hline
\end{tabular}

R Squared $=0.63$

Adjusted R Squared $\quad=0.54$

F- Statistics $\quad=54.83$

The regression result in Table 1 revealed that, the coefficient of determination $\left(\mathrm{R}^{2}\right)$ is 0.63 . This indicates that about $63 \%$ of change in the dependent variable return on asset (ROA) could be accounted for by the explanatory variable of board composition (BCOMP). The adjusted R-squared of $54 \%$ further justifies this effect. The F-value of 54.83 which is significant at $1 \%$ level indicate that there exists a significant relationship between the dependent and independent variable and that the modeldoes not suffer from specification bias.

The estimated coefficient for board composition (BCOMP) is negative, this implies that there exists an inverse relationship between board composition and performance of banks. In other words,increase in the proportionof non-executive director will lead to a corresponding decrease in the performance of the commercial banks in Cameroon. This result is in line with economic a priori criterial and is significant at $5 \%$ level of significance.

\section{DISCUSSION OF FINDINGS}

The findings of the second hypothesis of this study revealed that there exist a significant and negative relationship between board composition and the financial performance of commercial banks in Cameroon as measured by return on asset (ROA). This finding indicates that increase in the proportionof non-executive director will lead to a corresponding decrease in the performance of the commercial banks in Cameroon. One of the reasons why increasing board independence apparently 
doesn't pay off in improved performance is that having a reasonable number of inside directors could add value. A support for our view is the suggestion by Baysinger and Butler (1985) that an optimal board contains a mix of inside, independent, and perhaps also affiliated directors, who bring different skills and knowledge to the board.

Executive directors may also be better at strategic planning decision. This view is also consistent with Klein's (1998) evidence that inside director representation on investment committees of the board correlates with improved firm performance.

The negative effect can also be because non-executive directors are likely to be too busy with other commitments and are only involved with the company business on a 'part-time' basis.

In addition, as mentioned earlier, non-executive directors are likely not to have a hands-on approach or are not necessarily well versed in the business, hence do not necessarily make the best decisions. Our findings are in tune with the study by Pi and Timme (1993); Belkhir (2006); Staikouras et al. (2007) and Adams and Mehran (2005 and 2008) who found a negative but significant relationship between the tested variables. However, our findings disagree with Bebchuk et al. (2009) and Pathan et al. (2007) who found a positive relationship between the variables.

\section{CONCLuSion}

Based on the findings obtained from this study, the following conclusions could be made; the board composition which is the proportion of non-executive directors to the executive directors on the board meeting recorded a mean of $75 \%$. This means that on average, about $75 \%$ of the board members are outside directors (non-executive directors).Also,the regression analysis indicated that there exist a negative (-.463) between board composition (proposition of non-executive directors) and the financial performance of commercial banks in Cameroon as measured by ROA. This result was equally significant $(\mathrm{t}=-6.052, \mathrm{p}=.000)$. The negative sign observed here means that an increase in the nonexecutive directors on the board of directors will lead to a corresponding decrease in the financial performance of commercial banks in Cameroon

\section{RECOMMENDATIONS AND IMPLICATION OF STUDY}

Based on the findings of this research, we therefore present the following recommendations which will be useful to stakeholders.

1. Commercial banks in Cameroon should try to strike a fair balance between the proportion of nonexecutive and executive directors on the board of directors

2. Proponents of board independence should note with caution the negative relationship between board independence and future operating performance. Hence, if the purpose of board independence is to improve performance, then such efforts might be misguided. However, if the purpose of board independence is to discipline management of poorly performing firms or otherwise monitor, then board independence has merit. In other to have proper monitoring by independent directors, bank regulatory bodies should require additional disclosure of financial or personal ties between directors (or the organizations they work for) and the company or its CEO. By so doing, they will be more completely independent. Also, banks should be allowed to experiment with modest departures from the current norm of a "supermajority independent" board with only one or two inside directors.

\section{REFERENCES}

Adams R and Mehran H (2008): Corporate Performance, Board Structure and their Determinants in the Banking Industry. Federal Reserve Bank of NY Staff Report No 330

Akpan, N (2007): Internal Control and Bank Fraud in Nigeria. Economic Journal, Vol. 95, pp.118-132

Anderson, C.W., Becher, D.A., Campbell, T.L. (2004): Bank Mergers: The Market for Bank CEOs, and Managerial Incentives. Journal of Financial Intermediation Vol. 27, No. 3 Pp 89- 102

Anderson, R., Mansi, S and Reeb. D (2004) Board Characteristics, Accounting Report Integrity, and the Cost of Debt. Journal of Accounting and Economics 37 (September), Pp. 315-342.

Attiya Y. and Robina, Iqbal (2007): Relationship between Corporate Governance Indicators and Firm Value: A Case Study of Karachi Stock Exchange. MPRA Paper No. 2225

Baysinger, B. D. \& Butler, H.N. (1985): Corporate Governance and the Board of Directors: Performance Effects of Changes in Board Composition, Journal of Law, Economics, and Organization, Vol. 1, pp. 101-124 
Bebchuk, L., Cohen, A. and Ferrell, A. (2009). 'What Matters in Corporate Governance?' The Review of Financial Studies, Vol. 22, No. 2, pp.783-807

Belkhir, M. (2006): Board Structure, Ownership Structure, and Firm Performance: Evidence from Banking. Retrieved from www.papers.ssrn.com/so13/papers.cfm?on $13^{\text {th }}$ May 2008

Berle, S.S \& Means, G.C (1932). The Modern Corporation and Private Property. New York, Macmillan.

Bhagat, S and Black, B (1999): The Uncertain Relationship between Board Composition and Firm Performance, The Business Lawyer, Vol. 54, No. 3, Pp. 921-953.

Bhagat, S and Jefferis, R (2002): The Econometrics of Corporate Governance Studies, Cambridge, MIT Press,

Bhagat, S., Carey, D. C and Elson C. M. (1999): Director Ownership and Corporate Performance. American Economic Review Vol. 73 No. 4, Pp 82-97.

Bhagat, Sanjai and Bolton, Brian (2005): Corporate Governance and Firm Performance". Working Paper No.172005, University of Colorado.

Bhagat, Sanjai, and Bernard Black, (2002): The Non-Correlation Between Board Independence and Long-Term Firm Performance. Journal of Corporation Law, Vol. 27, Pp. 231-254.

Bohren, Oyvind and Bernt, Arne Odegaard, (2003): Governance and Performance Revisited. Working Paper 68, Norwegian School of Management.

Brickley, J.A., Coles, J.L \& Terry, R.L. (1994): Outside Directors and the Adoption of Poison Pills, Journal of Financial Economics, Vol. 35, pp 371-390.

Cadbury, A, (1992): Report of the Committee on the Financial Aspects of Corporate Governance. Gee Publishing, London

Cadbury, A. (2002): Overview of Corporate Governance: A Framework for Implementation. The World Bank Group; Washington. D.C: V-VI.

Daily, CEllstrand, A (1996): Boards of Directors: A Review and Research Agenda. Journal of Management. Vol. 22, No.3, pp 409 - 418.

Daily, C.M. \& Dalton, D.R. (1992): The Relationship Between Governance Structure and Corporate Performance in Entrepreneurial Firms, Journal of Business Venturing, Vol.7, No. 5, pp 375-386.

Daily, C.M., Dalton, D.R. and Canella, A.A. (2003): Corporate Governance: Decades of Dialogue and Data. Academy of Management Review, Vol.28, No.3, 371-382.

Flannery, M. J (1996): Financial Crisis, Payment Systems Problems, and Discount Window lending. Journal of Money, Credit and Banking. Vol. 28., No4. Pp. 58-65

Forsberg, R (1989): Outside Directors and Managerial Monitoring, Akron Business and Economic Review, Vol. 20, Pp. 24-32

Hanrahan, P, Ramsay, I and Stapledon, G (2001): Commercial Applications of Company Law, 2nd ed., Sydney, $\mathrm{CCH}$ Australia.

Heidi,V. B. \&Marleen, W. (2003): Voluntary Disclosure on Corporate Governance in the European Union. University of London Press

Hermalin, Benjamin E., and Michael S Weisbach, (1988): The Determination of Board Composition. RAND Journal of Economics, Vol.19, pp.589-606.

Hermalin, Benjamin E., and Michael S Weisbach, (1999): The Effects of Board Composition and Direct Incentives on Firm Performance, Financial Management, Vol. 20, pp. 101-112

Imam, Mahmood Osman. (2006): Firm Performance and Corporate Governance through Ownership Structure: Evidence from Bangladesh Stock Market. Paper presented in 2006 ICMAB Conference.

Iskander, Magdi R., and Chamlou, Nadereh (2000): Corporate Governance: A Framework for Implementation. Washington. D.C, The World Bank Group.

Klein, E (1998): Firm Performance and Board Committee Structure, Journal of Law and Economics, Vol. 41, No.2, pp. 275- 293

La Porta, R., Lopez-De-Silanes, F. and Shleifer, A. (1999): Corporate Ownership Around the World Journal of Finance, Vol. 54, pp.471-498.

Laing, D. and Weir, M (1999): Governance. Structures, Size and Corporate Performance. Organizational Dynamics, Vol.30 No.3, pp 310-324.

Mayes G. D., Halme L and Aarno, L (2001): Improving Banking Supervision. New York, Palgrave, Macmillan

Mehran, Hamid, (1995): Executive Compensation Structure, Ownership, and Firm Performance. Journal of Financial Economics, Vol.38, pp. 163-84.

Miyajima, H., Omi, Y and Saito N. (2003): Corporate Governance and Performance in Twentieth Century Japan: Business and Economic History Vol. 1, pp. 1-26

Nikomborirak, D (2001): An Assessment of The Role of Board of Directors in Building Good Corporate Governance: The Case of Thailand. The Third Asian Round Table on Corporate Governance, Thailand Development Research Institute, Bangkok. April, 7.

Ogus, A. I. (1994): Regulation, Legal Form and Economic Theory. Clarendon Law Series, Oxford, University Press.

Oluyemi, S.A (2006): Banking Sector Reforms and the Imperatives of Good Corporate Governance in the Nigerian Banking System. NDIC Quarterly Vol. 15 No. 1, March pp. 22-29 
Pathan S, Skully M and Wickramanayake, J. (2007): Board Size, Independence and Performance: An Analysis of Thai Banks. Asia-Pacific Financial Markets Vol.14, No.2, Pp 211-227.

Pearce, J.A. and Zahra, S.A. (1992): Board Composition from a Strategic Contingency Perspective Journal of Management Studies, Vol.29, No.4, 414-438.

Pfeffer, J. and Salancik, G.R. (1978): The External Control of Organisation: A Resource Dependency Perspective, New York: Harper and Roe

Pi, L. and Timme S.G. (1993): Corporate Control and Bank Efficiency. Journal Banking Finance Vol.21, No.7 pp 515-530.

Rosenstein, S and J.C Wyatt (1997): Outside Directors, Board Effectiveness and Shareholders Wealth, Journal of Financial Economics, Vol. 26, pp 175-191

Sanda, A.U, A.S Mukaila and T. Garba (2005): Corporate Governance Mechanisms and Firm Financial Performance in Nigeria, Final Report Presented to the Biannual Research Workshop of the AERC, Nairobi, Kenya, pp 24-29

Sang-Woo, Nam and Lum. A. (2004): Relationship Banking and Its Role in Corporate Governance. ADBI Research Paper, ADB Institute

Soludo, C. C. (2004a): Consolidating the Nigerian Banking Industry to Meet the Development Challenges of the 21st Century. Being an Address to the special Meeting of Bankers Committee, Held on July 6

Staikouras, C., Maria-Eleni, K., Agoraki, A., Manthos, D. and Panagiotis, K. (2007). The effect of board size and composition on bank efficiency. Retrieved from http://www.efmaefm.org/OEFMAMEETINGS/EFMA on 13th of October 2008

Tomasic, R, Pentony, B and Bottomley, S (2003): Fiduciary Duties of Directors: Interview Schedule, Personal Communication. Melbourne.

Vafeas, N. (1999): Board Meeting Frequency and Firm Performance, Journal of Financial Economics, Vol. 53 , pp. 113-132.

Vance, S (1983): Corporate Leadership: Boards, Directors and Strategy, New York, McGraw-Hill.

Weber, R. P., (1980): Basic Content Analysis, Sage University Paper Series No. 07- 049. 29

Weisbach, M.S (1988): Outside Directors and CEO Turnover, Journal of Financial Economics, Vol. 20, pp. 431-450.

Westham, H (2009) Corporate Governance in European Banks. A PhD Thesis submitted to the Department of Financial Economics, Hanken School of Economics, Finland

White, J and Ingrassia, P (1992): Board Ousts Managers at GM: Takes Control of Crucial Committee, The Wall Street Journal, April 7, pp. A1- A8.

Williamson O. 1970. Corporate Control and Business Behavior: An inquiry into the Effects of Organizational Form on Enterprise Behavior. Prentice-Hall, Englewood Cliffs, New Jersey

Yermack, D. (1996): Higher Market Valuation of Companies with a Small Board of Directors, Journal of Financial Economics, Vol.40, pp. 185-211.

Yeung B. (2000): “Comment.” in Concentrated Corporate Ownership. Morck RK (ed.) University of Chicago Press: 292-294

Yu, D (2003): Board of Directors, Corporate Governance and Performance: An Empirical Analysis of Listed Companies in China. Social Sciences in China Vol. 19, No. 4 Pp $231-245$.

Zahra, S and Pearce, J (1989): Boards of Directors and Corporate Financial Performance: a Review and Integrative Model, Journal of Managt, Vol. 15, No. 2, pp. 291-324.

Zahra, S. A. and Pearce, J. (2007). The Implications of Board of Directors' Composition for Corporate Strategy and Performance. International Journal of Management, Vol.5, No.2 Pp.229-236.

Citation: Emmanuel Kamdem, Gladys Njoukiang Asaah. "The Effect of Board Composition on the Financial Performance of Commercial Banks in Cameroon" International Journal of Managerial Studies and Research (IJMSR), vol 9, no. 9, 2021, pp. 21-28. doi: https://doi.org/10.20431/2349-0349.0909003.

Copyright: () 2021 Authors. This is an open-access article distributed under the terms of the Creative Commons Attribution License, which permits unrestricted use, distribution, and reproduction in any medium, provided the original author and source are credited. 